\title{
EFFECTIVENESS OF LOW IMPACT AEROBIC EXERCISE ACTIVITY ON ANXIETY LEVELS IN SCHIZOPHRENIA PATIENTS AT DR.RM SOEDJARWADI HOSPITAL, KLATEN
}

\author{
Rita Untari \\ School of Health Polytechnics, Surakarta
}

\begin{abstract}
Background: The positive and negative symptoms of schizophrenia can cause anxiety symptoms. This anxiety makes people with schizophrenia tend to remain silent, avoid other, and ignore daily activities. Performing daily activities requires good motor and coordination skill. Structured performance exercise (gymnastics) can affect anxiety symptoms. This study aimed to determine low impact aerobic exercise activity on anxiety levels in schizophrenia patients at dr.rm soedjarwadi hospital, Klaten, Central Java.

Subjects and Method: This was a pre-experimental one-group pretest-posttest design was conducted at Psychosocial Rehabilitation Unit of Dr.RM. Soedjarwadi Psychiatric Hospital, Klaten, Central java from January to February 2019. A sample of 21 people with an age range of 19-50-year schizophrenia patients who received a psychosocial rehabilitation selected by purposive sampling. The dependent variable was the level of anxiety. The independent variable was a low impact aerobic exercise. The data were collected by Hamilton Rating Scale for Anxiety (HARS). The data were analyzed by t-test.

Results: The level of anxiety before the intervention (Mean $=27.52)$ was higher than after the intervention (Mean $=20.43)$, and it was statistically significant $(\mathrm{p}<0.001)$.

Conclusion: Low impact aerobic exercise activities lower the anxiety level of schizophrenia patients at RSJD dr. RM Soedjarwadi, Central Java Province. Schizophrenic patients are encouraged to participate in low impact aerobic exercise held in psychosocial rehabilitation installation.
\end{abstract}

Keywords: Schizophrenia, Low Impact Aerobic Gymnastics, Anxiety Level

\section{Correspondence:}

Rita Untari. School of Health Polytechnics, Surakarta. Jl. Letjen Soetoyo Mojosongo, Surakarta. Email: ritauntari@gmail.com. Mobile: 08164278544

The $7^{\text {th }}$ International Conference on Public Health Solo, Indonesia, November 18-19, 2020 383 https://doi.org/10.26911/the7thicph.05.15 